\title{
Tsunamis Generated by Subaquatic Volcanic Explosions: Unique Data from 1996 Eruption in Karymskoye Lake, Kamchatka, Russia
}

\author{
Alexander Belousov, ${ }^{1}$ Barry Voight, ${ }^{2}$ Marina Belousova ${ }^{1}$ and \\ YAROSLAV MURAVYEV ${ }^{3}$
}

\begin{abstract}
The 1996 subaquatic explosive eruption near the northern shore of Karymskoye Lake in Kamchatka, Russia, generated multiple tsunamis. We document the explosive process that produced the tsunamis, and describe the tsunami effects and runup around the 4-km diameter lake. These data enable the determination of an attenuation relation of runup (wave) height for these "explosive" tsunamis, which is compared with theoretical models of wave height distributions. For the proximal zone, involving radial distances $(r)$ up to $1.3 \mathrm{~km}$ from the source, the runup height $(R)$ shows rapid attenuation (from $>30 \mathrm{~m}$ to $8 \mathrm{~m}$ ) with distance as $\log R=-1.98 \log [r]+2.6$. For the distal zone, $r>1.3 \mathrm{~km}$, involving mainly wave travel southeastwards along the body of the lake away from the explosion source, $R$ decays more slowly (from $8 \mathrm{~m}$ to $3 \mathrm{~m}$ ) as $\log R=-0.56 \log [r]+1.9$. Rapid decay in the proximal zone suggests that near the source of the explosion, the tsunami propagated radially as a collapsing wave (bore) with discontinuous change in height. The break-in-slope of the runup plot at $1.3 \mathrm{~km}$ suggests that beyond this distance the tsunami propagated approximately as a decaying one-dimensional wave in a channel of approximately constant width.
\end{abstract}

Key words: Tsunami of volcanic origin, base surge, tsunami runup, underwater volcanic explosion, Karymskoye Lake, Kamchatka.

\section{Introduction}

About 100 tsunami events of volcanic origin have been reported in historic time. They are caused by a wide range of processes accompanying eruptions, including volcanic earthquakes, caldera subsidence, pyroclastic flows or avalanches of hot or cold rocks, landslides and, in $29 \%$ of cases reported, by subaquatic volcanic explosions (LATTER, 1981). Understanding the mechanisms of the generation and propagation of volcanic tsunamis is important because the tsunamis strongly

\footnotetext{
${ }^{1}$ Institute of Volcanic Geology and Geochemistry, Piipa Blvd, 9, Petropavlovsk-Kamchatsky 683006, Russia.

${ }^{2}$ Department of Geosciences, The Pennsylvania State University, Deike Building, University Park, Pennsylvania 16802, U.S.A.

${ }^{3}$ Institute of Volcanology, Piipa Blvd, 9, Petropavlovsk-Kamchatsky 683006, Russia.
} 
expand the destructive potential of many submarine and coastal volcanoes (KIENLE et al., 1987). Tsunamis generated by volcanic explosions are particularly poorly understood because of the rarity of observational data. Wave-gauge records have been created for only two tsunamis apparently generated by explosive eruptions, from Krakatau, Indonesia, in 1883 (Verbeek, cited in EwING and Press, 1955) and Myojinsho Volcano, Japan, in 1952 (UNOKI and NAKANO, 1963). However, for the Krakatau data, there is no conviction that the tsunamis were generated only by explosions because the eruption was also accompanied by strong earthquakes, caldera subsidence, and mass movements (including large pyroclastic flows) (CAREY et al., 1996).

Here we report the results of our observations of the 1996 subaquatic explosive eruption at Karymskoye intracaldera lake. This event generated multiple tsunamis, and we document the tsunami effects and runup. These data enable the determination of an empirical law of attenuation of runup (wave) height for these "explosive" tsunamis. Results are then compared to theoretical modeling.

\section{The 1996 Eruption}

Karymskoye freshwater lake is located in the uninhabited part of the eastern volcanic belt of Kamchatka (Fig. 1). The eruption in the lake started in the afternoon on January 2, 1996 and continued for some 10 to 20 hours (MURAVYEV et al., 1997; Belousov and Belousova, 1999). By the time of the initial observation during an overflight on January 2 at 15:40 to 16:10 local time, the ice cover of the lake had melted, and a phreatomagmatic eruption of the Surtseyan type was in progress from a vent off the northern shore. Initial water depth here was approximately $40-50 \mathrm{~m}$, compared to the maximum lake depth of $70 \mathrm{~m}$. The diameter of the lake is about $4 \mathrm{~km}$.

Explosions occurred every 4 to $12 \mathrm{~min}$. Six explosions were observed with an average interval of $6 \mathrm{~min}$. Between the explosions the lake water was relatively calm, displaying only intensive bubbling and steaming. The strongest explosions initially produced a rapidly rising, smooth-surfaced bulbous mass of expanding gas and pyroclasts maintained by surface tension within a shell of water. Within seconds the shell expanded to $450 \mathrm{~m}$ high, then became unstable and was pierced by multiple jets of a black mixture of pyroclasts with steam and water, of the type named "cock's tail" or "cypressoid" jets by THORARINSSON (1967). Analysis of videotape of a number of explosions recorded by V. Bakhtiarov during the overflight shows that the maximum velocity of the jets was about $110 \mathrm{~m} / \mathrm{s}$.

Simultaneously with the above, a light gray "collar" appeared around the focus (epicenter) of the explosion, representing a nearly axially-symmetric elevation of the water surface $130 \mathrm{~m}$ high that propagated radially at about 40 to $20 \mathrm{~m} / \mathrm{s}$ to form the tsunami. Meanwhile, within 15 seconds of the beginning of the explosion, the 


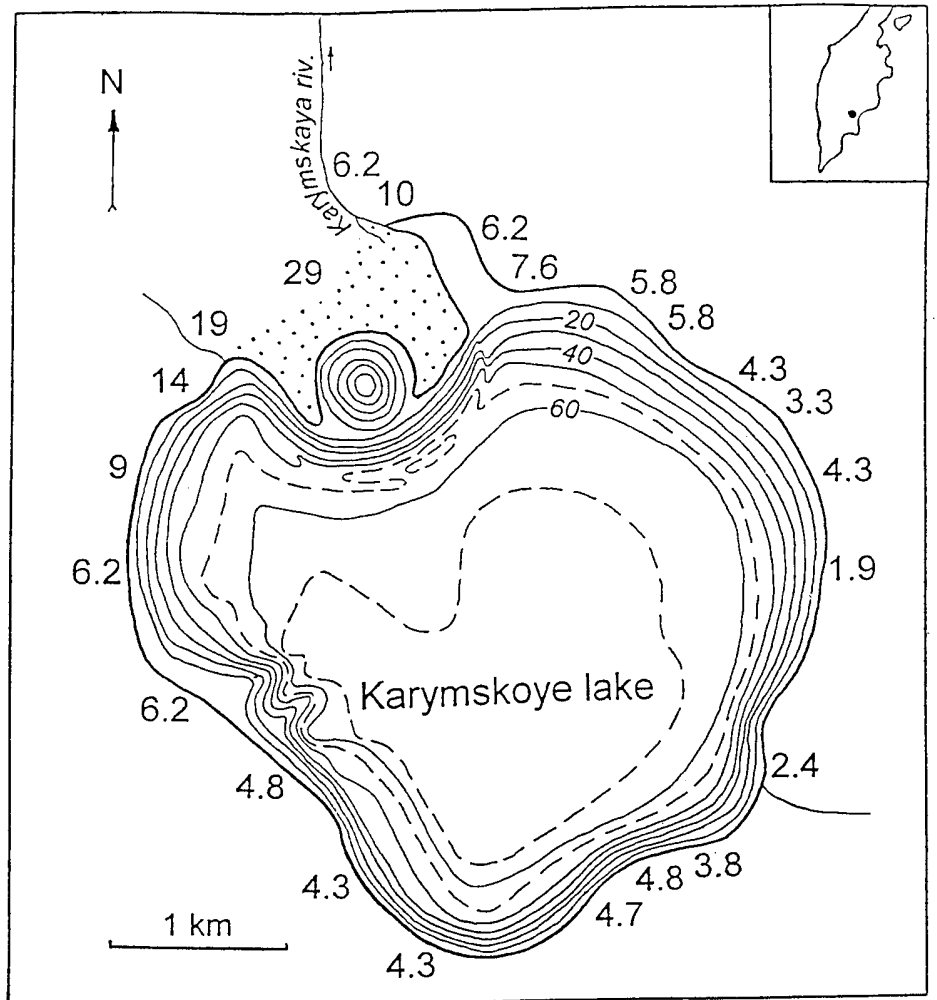

Figure 1

Karymskoye Lake, with inset showing location in Kamchatka, Russia. Numbers around lake are tsunami runup heights (m); bathymetry contours (after the eruption) in meters. Stippled area on north shore is new land formed in eruption, partly enclosing underwater crater defined by bulls-eye bathymetry pattern.

cypressoid jets reached their maximum height of about $1 \mathrm{~km}$, and then collapsed back toward the lake to produce a base surge of pyroclasts, water droplets, and steam, that moved radially from the stem of the eruptive column with a maximum velocity of $20 \mathrm{~m} / \mathrm{s}$ (Fig. 2). The interaction between the propagating base surge and the surface of the lake water contributed to a complex wave formation. Above the stem a white, pyroclast-depleted eruptive cloud convected to an altitude of approximately $3 \mathrm{~km}$.

Some of the observed explosions were weaker than the example described above. Most of the explosions produced a single, near-vertical, column-like jet of black gas-water-pyroclastic mixture about $100-150 \mathrm{~m}$ high. The column then collapsed back into the lake, producing only a subtle base surge.

The eruption formed an underwater tuff ring of basaltic composition (52-53\% $\mathrm{SiO}_{2}$ ), with the deposit volume approximately $0.047 \mathrm{~km}^{3}$ (Fig. 3). The tuff ring 


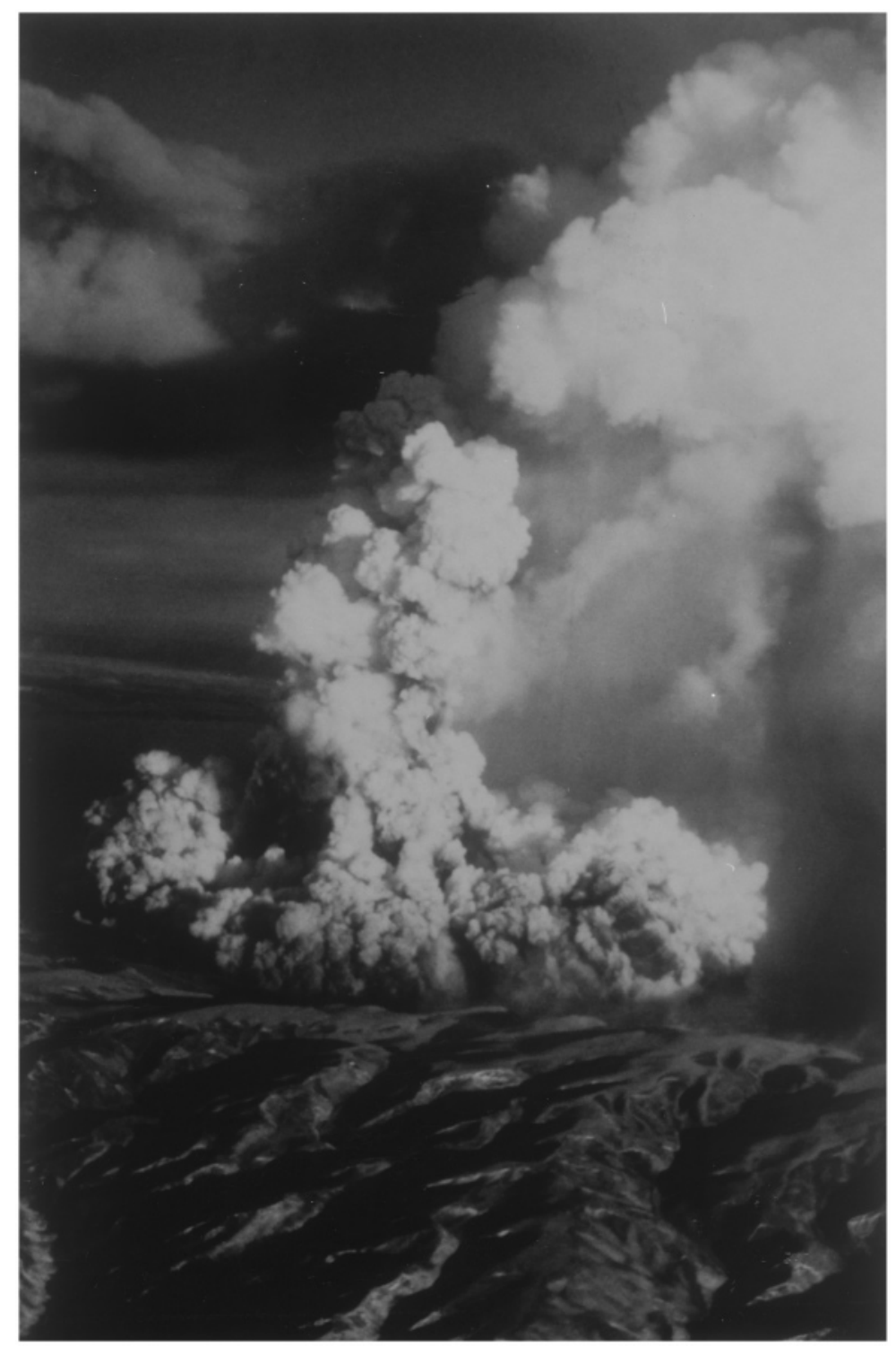

Figure 2

Sub-lacustrine volcanic explosion in Karymskoye Lake at 15:43 local time, January 2, 1996. View from SW. Collapse of eruptive column has produced base surge moving outward along the surface of the lake. Diameter of the base surge about $1.2 \mathrm{~m}$.

consists of sandy gravel layers, $10-60 \mathrm{~cm}$ thick, each bed representing a single explosion. Taking on the nominal deposit thickness as $50 \mathrm{~m}$ and the average proximal bed thickness as $25 \mathrm{~cm}$, on the order of 200 explosions occurred, with the average production about $2 \times 10^{5} \mathrm{~m}^{3}$ of tephra per explosion. 


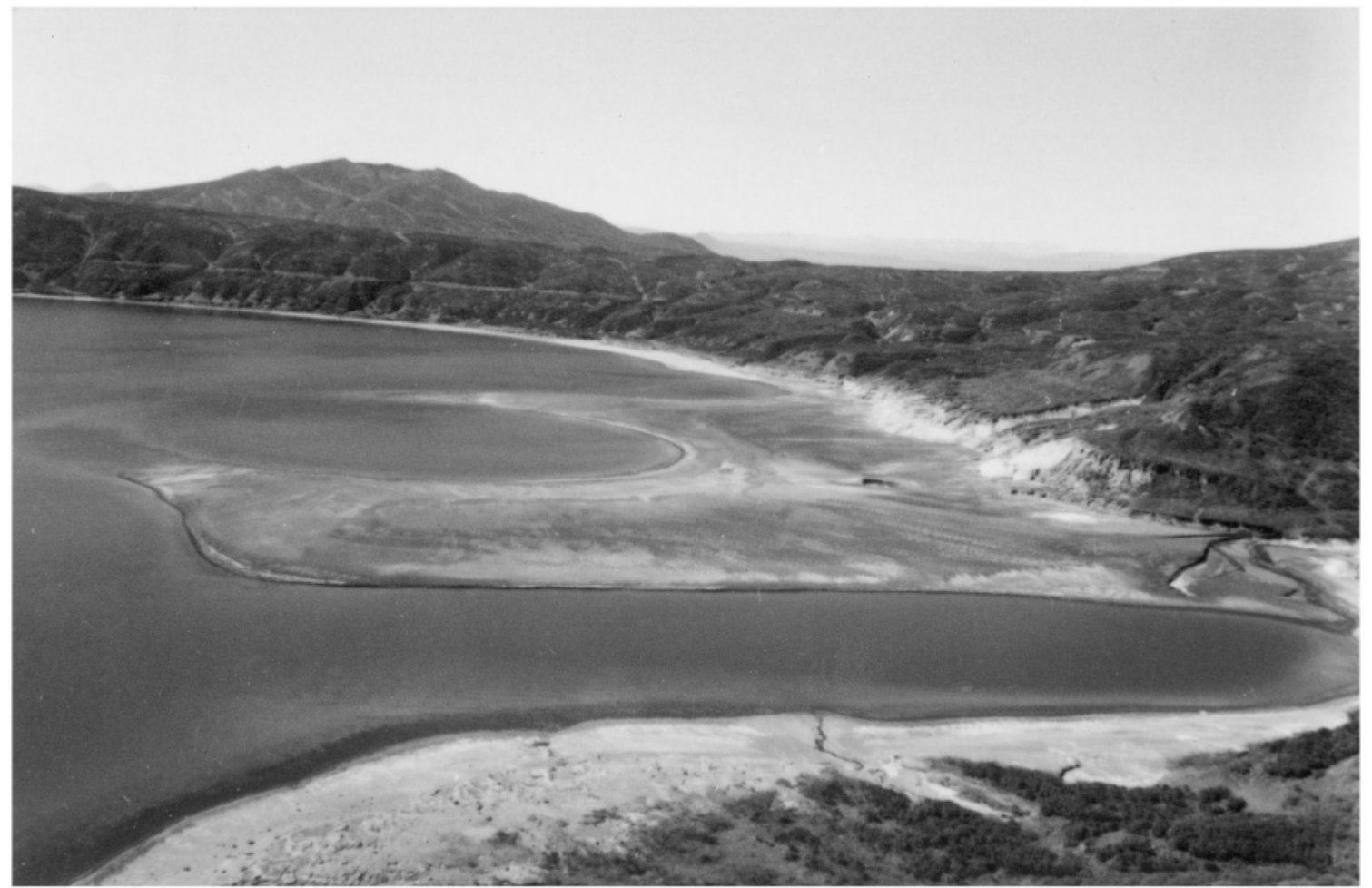

Figure 3

Partly emergent tuff ring in Karymskoye Lake, with crater $600 \mathrm{~m}$ in diameter, formed by 1996 eruption. View from NE. The tuff ring partially emerged when the water level lowered after the eruption. Note strong tsunami erosion on north shore. 
The steep northern shore of the lake adjacent to the tuff ring was violently eroded by the tsunamis and surges, with all the plants and soil more than $1.5 \mathrm{~m}$ thick stripped off and poorly consolidated bedrock exposed (Fig. 3). The damage was produced not only by water waves, but also by vigorous flows of water droplets and water-pyroclastic mixture ejected by explosions from the crater. Along the rest of the shoreline, more than $1.3 \mathrm{~km}$ from the crater, the tsunamis carved new cliffs extending $3 \mathrm{~m}$ high, eroded the upper layer of hard (frozen) soil up to $50 \mathrm{~cm}$ thick, and inundated adjacent areas as shown by vegetation removal, or by the destruction of alder bushes. Within the band of devastation the tsunamis deposited several discontinuous, finely laminated layers of sand and gravel up to $35 \mathrm{~cm}$ thick, with scattered pebbles, fragments of plants, and clots of soil.

\section{Runup Measurements}

The distinctive band of devastation, as well as the tsunami deposits, allowed us to measure the runup height of the tsunamis at 24 points around the lake (Fig. 4). When we measured the runup in September 1996, the level of the lake was approximately equal to that before the eruption. However, during the eruption, the level of the lake was rising due to several processes. The most important of these processes was the deposition of pyroclasts into the lake and the decrease of outflow from the lake as a result of the blockage of the Karymskaya river outlet by a pyroclastic dam. The level reached its maximum of $2.6 \mathrm{~m}$ above normal several

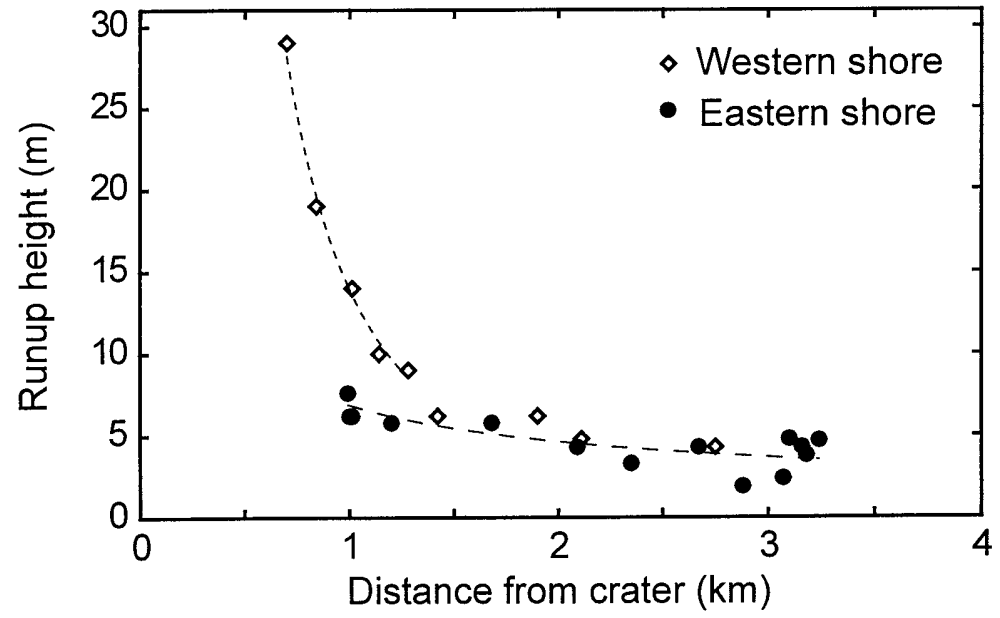

Figure 4

Runup height, $R$ vs. distance from the crater, $r$. Note change in trend about $1.3 \mathrm{~km}$ from the crater, Dotted line gives log decay as discussed in text. Dashed line is best fit to our data that approximately matches $1 / r^{1 / 2}$ decay. 
months after the eruption, and then, when the pyroclastic dam was breached and eroded, receded to the pre-eruption level (MURAVYEV et al., 1997). Because of the above considerations, we assumed the level of the lake during the eruption to be about $1 \mathrm{~m}$ higher than normal for our analysis. Thus the runup data in Figure 4 show the elevation data of actual runup measurements minus $1 \mathrm{~m}$.

Because there were several tsunamis, the measurements represent the runup of the strongest event(s). The highest runups $(20-30 \mathrm{~m})$ occur on the shore immediately adjacent to the tuff ring, $700 \mathrm{~m}$ from the center of the crater. For the proximal zone, radial distances $(r)$ up to $1.3 \mathrm{~km}$, the runup height $(R)$ shows rapid attenuation with distance as $\log R=-1.98 \log [r]+2.6$. For the distal zone, $r>1.3$ $\mathrm{km}$, mainly involving southeastern wave travel along the body of the lake away from the explosion source, $R$ decays more slowly as $\log R=-0.56 \log [r]+1.9$. For the most distant points runup was $2-3 \mathrm{~m}$.

\section{Discussion}

The above results can be compared to theoretical distributions of water waves, noting that surface wave theory is available only for special initial configurations, such as infinite water depth (PoISSON, 1816), or constant finite depth (KRANZER and Keller, 1959). A further issue is the linkage between runup height and "deep-water" wave height, understood for simple geometric aspects (e.g., periodic non-breaking wave propagating from constant depth), but with many unresolved questions and no solutions directly applicable to the variable depths and oblique wave propagation and refraction found at Karymskoye (SYNOLAKIS, 1987; Keller and Keller, 1964; Slingerland and Voight, 1979). To a first approximation it might be assumed that normalized runup and normalized wave height are approximately proportional, considering that beach slopes are similar in most sectors (HALL and WATTS, 1953); thus it is possible to consider runup decay as a measure of wave height attenuation. Of significance is that an impulsive axial-symmetric wave decays as $1 / r$ in water of finite depth, but as $1 / r^{1 / 2}$ in a one-dimensional channel, in this case letting $r$ be the one-dimensional distance (KRANZER and KELLER, 1959).

Comparing these relations to Figure 4, the proximal decay is seen to be considerably more rapid than either relation indicated above, suggesting that in the near field of the explosion the tsunami did not propagate as a radial solitary wave. Apparently the waves were preceded by a bore with discontinuous change in height. The conclusion is qualitatively supported by the strong erosive capacity of the wave. On the other hand, the break-in-slope of the runup plot at $1.3 \mathrm{~km}$ suggests that tsunami propagation changed properties here; distal attenuation was slower and wave erosion far weaker. Indeed, the distal relation is nearly identical to wave decay by the $1 / r^{1 / 2}$ law, suggesting that once the wave segments simultaneously 
intersected both the SW and NE shores, the tsunami then propagated toward the southeast (Fig. 1) as a decaying one-dimensional wave in a channel of approximately constant width. Finally, an interesting theoretical aspect is that as water is lost (thrown skywards) during the explosion, a negative bore should be expected near the core of the explosion, travelling approximately with the velocity $(g h)^{1 / 2}$, where $h$ is the depth, with other waves following by prescribed delay time (KrANZer and Keller, 1959). We have no observations to support this proposition, as explosion clouds precluded observations in this region.

\section{Acknowledgements}

We are very grateful to Sergei Fazlullin, Alexei Ozerov, Sergei Ushakov, Elena Grib, and Evgenii Gordeev who participated with us in the field at Karymskoye Lake and with whom we have had very helpful discussions. We acknowledge Vilorii Bakhtiarov who kindly provided us with a videotape of the eruption. Preparation of the manuscript was made during the postdoctoral fellowship of Alexander Belousov and Marina Belousova at Pennsylvania State University. The research described in this publication was made possible, in part, by NSF Grants 94-14622 and RG1-172 from the Civilian Research and Development Foundation and the Russian Government.

\section{REFERENCES}

Belousov, A., and Belousova, M. (1999), Eruptive Process, Impact and Deposits of the 1996 and Ancient Basaltic Phreatomagmatic Eruptions in Karymskoye Lake (Kamchatka, Russia), Sedimentology (in press).

Carey, S., Sigurdsson, H., Mandeville, C., and Bronto, S. (1996), Pyroclastic Flows and Surges over Water: An Example from the 1883 Krakatau Eruption, Bull. Volcanol. 57, 493-511.

EwIng, M., and Press, F. (1955), Tide-gage Disturbances from the Great Eruption of Krakatoa, Trans. Amer. Geophys. Un. 36-1, 53-60.

Hall, J. V., and WatTs, G. M. (1953), Laboratory Investigation of the Vertical Rise of Solitary Waves on Impermeable Slopes, Beach Erosion Board, US Army Corps Eng. Tech. Memo 33.

Keller, J. B., and Keller, H. B. (1964), Water Wave Run-up in a Beach, Office Naval Research Res. Rept. NONR-3828(00), Dept. Navy, Washington.

Kienle, J., Kowalik, Z., and Murty, T. S. (1987), Tsunamis Generated by Eruptions from Mount St. Augustine Volcano, Alaska, Science 236, 1142-1147.

Kranzer, H. C., and Keller, J. B. (1959), Water Waves Produced by Explosions, J. Appl. Phys. 30, $398-407$.

Latter, J. H. (1981), Tsunamis of Volcanic Origin: Summary of Causes with Particular Reference to Krakatoa, 1883, Bull. Volcan. 44, 467-490.

Muravyev, Y. D., Fedotov, S. A., Budnikov, V. A., Ozerov, A. Y., Maguskin, M. A., Dvigalo, V. N., Andreev, V. I., Ivanov, V. V., Kartasheva, L. A., and Markov, I. A. (1997), Volcanic Activity in the Karymsky Centre in 1996: A Summit Eruption of Karymsky Volcano and a Phreatomagmatic Eruption in the Akademiya Nauk Caldera, Volcanol. Seismol. 5, 38-70 (in Russian).

Poisson, S. D. (1816), Mem. Acad. Roy. Sci. 1, Paris. 
Slingerland, R., and Voight, B., Occurrences, properties and predictive models of landslide-generated water waves. In Rockslides and Avalanches (ed. B. Voight) (Elsevier, Amsterdam 1979) pp. 317-397.

Synolakis, C. E. (1987), The Runup of Solitary Waves, J. Fluid Mech. 185, 523-545.

Thorarinsson, S., Surtsey: The New Island in the North Atlantic (Viking Press, New York 1967).

Unoki, S., and Nakano, M. (1963), On the Cauchi-Poisson Waves Caused by the Eruption of a Submarine Volcano, Oceanogr. Mag. 4, 119-141.

(Received May 28, 1998, revised December 1, 1998, accepted December 4, 1998) 